\title{
MCDM, OPERATIONAL RESEARCH AND SUSTAINABLE DEVELOPMENT IN THE TRANS-BORDER LITHUANIAN-GERMAN- POLISH CO-OPERATION
}

\author{
Oleg Kaplinski, Friedel Peldschus, \\ JOANICJUSZ NAZARKO, ARTURAS KAKLAUSKAS, \\ ROMUALDAS BAUŠYS
}

Corresponding author:

Oleg Kaplinski

Poznan University of Technology, Poland e-mail: oleg.kaplinski@put.poznan.pl

Friedel Peldschus

Leipzig University of Applied Sciences, Germany, email: friedel@peldschus.net

Joanicjusz Nazarko

Bialystok University of Technology, Poland e-mail: j.nazarko@pb.edu.pl

Arturas Kaklauskas

Vilnius Gediminas Technical University, Lithuania e-mail: arturas.kaklauskas@vgtu.It

Romualdas Baušys

Vilnius Gediminas Technical University, Lithuania e-mail: romualdas.bausys@vgtu.It

\section{INTRODUCTION}

The cooperation between three academic centres - Vilnius Gediminas Technical University (Lithuania), Leipzig University of Applied Sciences (Germany) and the Poznan University of Technology (Poland) - in the area of theory and application of Multiple-Criteria Decision-Making (MCDM), in what is broadly understood as the field of construc- tion, was both inspired and initiated by Dr Edmundas K. Zavadskas from the Vilnius Institute of Construction. It began with the Professor's scientific scholarship for a traineeship at the Leipzig University of Applied Sciences (Technische Hochschule Leipzig) in 1980-1981. The German side of the partnership was represented by Prof. Kurt Fiedler and Dr Friedel Peldschus, and the Polish side - by Prof. Oleg 
Kapliński. In 1986, this collaboration took the form of systematic scientific seminars, which were dubbed "Colloquia" by the organisers. Subsequent years saw the involvement of other academics such as, among others, Prof. Reinhard Seeling from Aachen (RWTH) who organised the 7th Colloquium in 1999. The Colloquia occur every two years in Germany, Lithuania and Poland. The 17th Colloquium will be held in May 2019 in Vilnius.

This form of cooperation not only resulted from the need to exchange experience and confront scientific achievement but also allowed access to a wider scope of information, periodicals and books, which the collaborating centres had at their disposal. It also created a possibility to have the results of scientific work published in journals from Germany, Lithuania and Poland. Additionally, it established a platform where doctoral and habilitation dissertations could be offered for consultations and professors from individual centres were and are still invited to review promotional theses. The knowledge accumulated by the cooperating centres, namely, multiple criteria methods (Vilnius), the development and application of gaming theories (Leipzig), and the queueing and reliability theories (Poznań), was combined and created a synergy which gave rise to many original MCDM methods.

The subject matter addressed by subsequent Colloquia kept evolving. First Colloquia were dominated by mathematical methods in the organisation of construction processes, planning instruments and, generally, elements of theory for decision-making. Later, presentations were offered concerning decision support systems, expert systems, controlling, life cycle, cash flow, IT, production economics, new educational methods, e-business, sustainable development in production engineering \& management and intelligent green construction. The most recent Colloquia (of 2011 and later) dealt with new multipurpose evaluation methods, application peculiarities related to various methods used for practical problems as well as elements of biometrics and neurosophia. Next, issues connected to neural design are expected to be addressed.

MDCM methods that were developed by the team lead by Prof. Zavadskas evolved the most. New methods consider fuzzy and grey numbers. Verbal decision methods also gained some attention. There was much significance attached to criteria normalisation and the problem of weights. New, hybrid models of MDMC methods were presented.
Fig. 1 shows the Colloquia calendar and addressed topics. It is not only a characteristic and evolutionary way to consider the mentioned methods, research interests and applications but, above all, the transition from micro to macro issues. Initially, research work focused on production and technological (construction) processes, hence dealing only with a building site. Gradually, on account of having to consider economic criteria, the subject matter expanded to real estate, construction projects and companies. This evolution corresponded to needs resulting from political and economic changes as well as new education requirements posed to universities of technology.

\section{DeVELOPMENT OF THE TRANS- BORDER COOPERATION}

On the international scene, regular scientific meetings involving three academic centres from Lithuania, Germany and Poland was a rather unusual phenomenon, but this type of trans-border cooperation earned much praise.

The experience gained through subsequent Colloquia showed the necessity for underlining the significance of shared achievements by popularising them and, most of all, making them more international. Participants of the Colloquia and especially employees of the Vilnius Gediminas Technical University (previously VISI) established several subjectrelated scientific periodicals. Most of them are already cited by ISI Web of Science of the Thomson Reuters Services.

The output of the Colloquia consists of several dozen monographs and several hundred articles. In 2009, three works were distinguished by Essential Science Indicators $[\mathrm{SM}]$ of Thomson Reuters for the greatest percentage increase of citations:

- as New Hot Papers in the field of Engineering, the paper by Zavadskas et al. (2008),

- in the field of Economics \& Business, the paper by Ginevicius et al. (2008),

- as Fast Breaking Paper in the field of Economics \& Business, the paper prepared by Turskis (2008). The subject matter addressed during the Colloquia always touched upon new trends, both in theory and practice, and there was always a need to expand the range of research topics. The addressed problems evolved from the modelling of construction (industrial) processes to project management. The combi- 


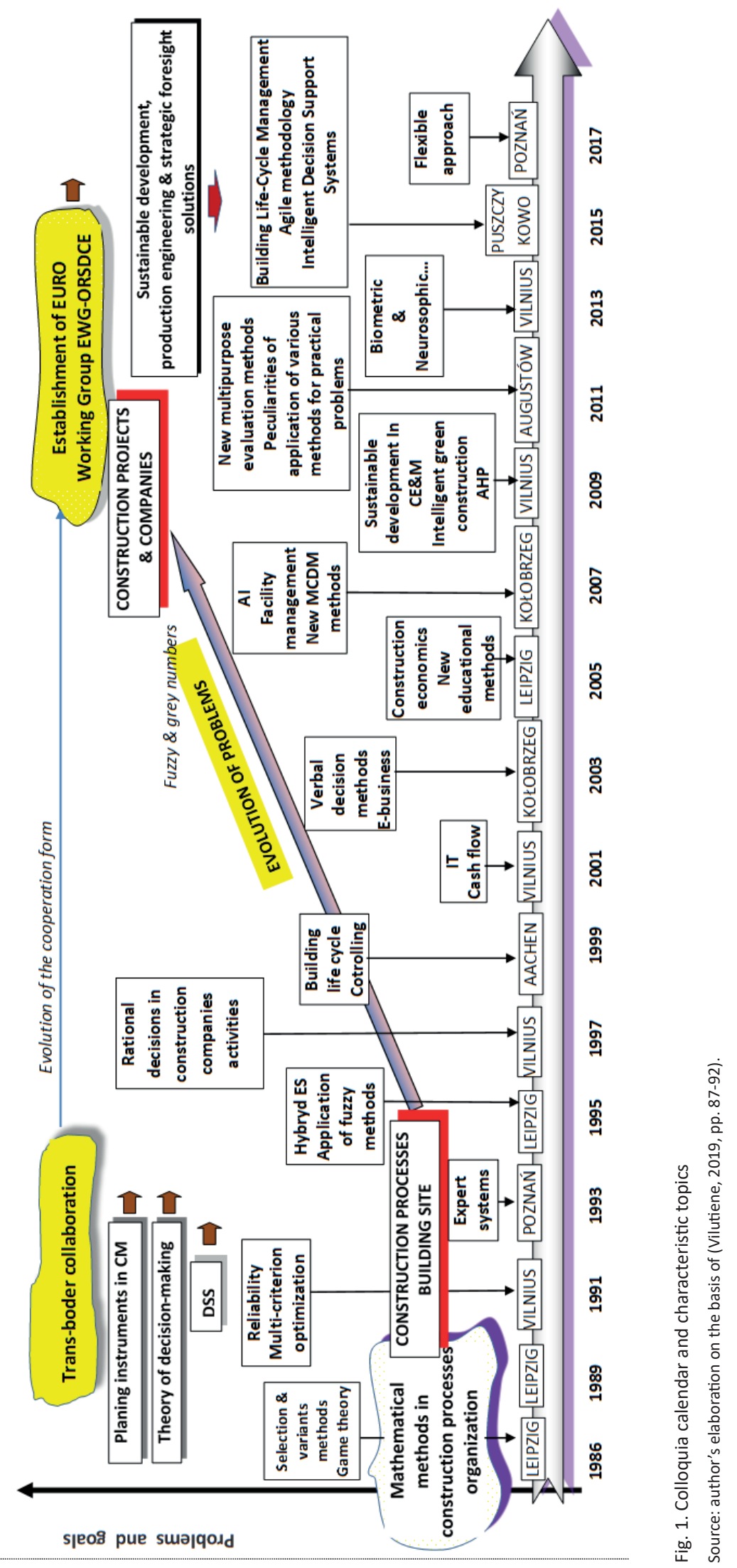


nation of Operational Research methods and sustainable development gave a stimulus to look for new applications. During the 12th Colloquium (2009), it was decided that the cooperation had to focus mainly on becoming a platform for young research practitioners who could share their experience and ask advice while developing their dissertations. The meetings consulted and initially assessed several research promotion texts. The Colloquia also opened opportunities for participants to extend their research volume, which was a significant factor in the advancement of their academic careers.

The establishment of the Colloquia created a basis for the development (through the initiative of Prof. Zavadskas) of the new EURO Working Group EWG-ORSDCE - "Operational Research in Sustainable Development and Civil Engineering (EWGORSDCE)." The Executive Committee of the Association of European Operational Research Societies (EURO) approved this Group during the 23rd annual European Conference on Operational Research "OR Creating Competitive Advantage", which took place in Bonn, Germany, 5-8 July 2009. Currently, the group joins 80 members from 19 countries (Lithuania, Germany, Poland, the United Kingdom, Belgium, Denmark, Netherlands, Portugal, Latvia, Estonia, the Czech Republic, Slovenia, Romania, Peru, Mexico, Russia, Ukraine, Australia and the USA). (Tamosaitiene et al., 2010). More detailed information concerning EWG-ORSDCE, its objectives, members, publications in the field of Operational Research and activities of the EURO Working Group OR in Sustainable Development and Civil Engineering (EWG-ORSDCE) can be found on its official website http://www.orsdce.vgtu.lt.

\section{ABOUt PROFESSOR EDMUNDAS K. ZAVADSKAS}

In 1990, Professor Edmundas K. Zavadskas became the first democratically elected rector of the Vilnius Institute of Construction. The transformation of the institute into Vilnius Technical University, to a large extent, was owed to his efforts. Later, the University also added the name of the Grand Duke Gediminas to the title. The University staff elected Prof. Zavadskas to the rector's position twice more, which he held for a total of 12 years, later acting as vice-rector for nine more years. During his terms of office, Professor Zavadskas maintained close coopera- tion with Polish universities, including the Białystok University of Technology.

His influence on the development of good relations with Poland is attested by the fact that Prof. Zavadskas was one of the founders of the Adam Mickiewicz Foundation - an organisation working towards the improvement of Lithuanian and Polish relations (1998). He was decorated with the medal for "Integral Humanism", awarded by a Polish journal "LITHUANIA" and a Lithuanian journal "KULTUROS BARAI". In 2001, he was univocally elected as a member of the Civil Engineering Committee of the Polish Academy of Sciences. Additionally, for his outstanding achievement in the development of cooperation between Poland and Lithuania, Professor Zavadskas was honoured by the Presidium of the Assembly of Parliamentarians to the Sejm of the Republic of Poland and the Seimas of the Republic of Lithuania with the "Nagroda Obojga Narodów" (Award of Both Nations) (2004), which he received in July 2004, at the Oratorium Marianum assembly hall of the University of Wrocław.

In 2002, the Poznań University of Technology (based on recommendations from supporting senates of the Warsaw University of Technology, Wrocław University of Technology and Gdańsk University of Technology) conferred the title of Doctor honoris causa on Prof. Zavadskas for the "Cooperation of academic communities in the spirit of integral humanism." Prof. Zavadskas is also a laureate of numerous other international awards and distinctions.

For many years, Prof. Zavadskas focused his research efforts on the issue of MCDM, which finds its application in various areas of technical, economic and social sciences. The monograph Multiple Criteria Evaluation of Projects in Construction (Vilnius, Technika 1994) by Zavadskas, Peldschus and Kaklauskas, received a review by professors Erhan Kozan and Martin Skitmore from the Australian Queensland University of Technology, which appeared in 1997 in the journal "Construction Management and Economics" (Taylor \& Francis). According to the review, the book initiated a new era of scientific research in construction concerning MCDM methods.

Articles by Prof. Zavadskas were published in 84 journals referenced in the Clarivate Analytics database. Many of them were published in Q1 (High Quality Publications) of the Elsevier publishing company, such as "Applied Soft Computing", "Expert Systems with Application", "European Journal of Operational Research", "Buildings and Environment", 


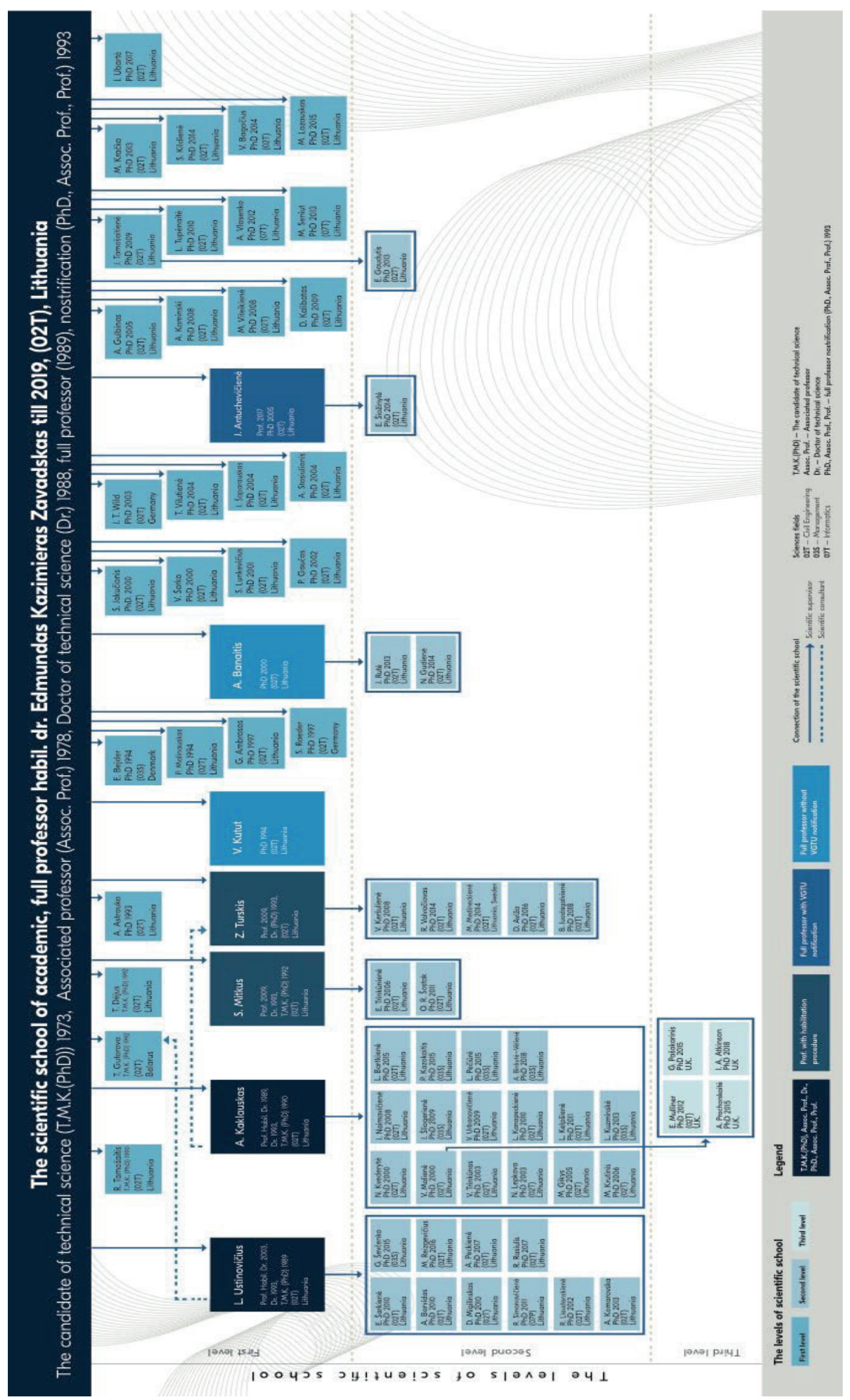

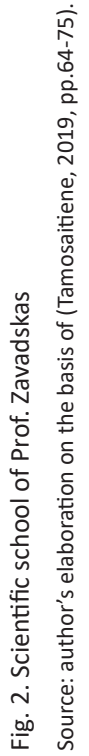


"Energy and Buildings", "Engineering Application of Artificial Intelligence", "Omega. The International Journal of Management Science" and "Land Use Policy". Thomson Routers deemed his 18 articles to be "Hot Papers". For many years, Prof. Zavadskas continued to cooperate internationally. He co-authored many publications together with scientists from 35 different countries (such as Belgium, Denmark, India, Iran, Canada, Germany, Poland, Sweden, the United States or Taiwan).

The Clarivate Analytics database has 462 his publications indexed, cited 10891 times in 4010 articles, with $\mathrm{H}=55$. In 2018, he was cited 2088 times. 469 articles are referenced in the SCOPUS database and cited 12302 times in 4663 articles, with $\mathrm{H}=58$. In 2018 alone, Prof. Zavadskas was cited 2286 times (20\% self-citation). Google Scholar has 812 publications cited 21242 times, with $\mathrm{H}=77$. In 2018, the number of citations was 3681 .

Prof. Zavadskas established a scientific school, which now includes scientists from three generations: his former doctoral students (35), doctoral students of doctors whose dissertations he promoted (approx. 30 ), and the third-generation doctoral students (2). About 20 former colleagues of Prof. Zavadskas have become professors themselves. Not only these academics currently work in Lithuania but have also dispersed throughout the entire world, including such countries as Poland, Great Britain, Ireland, Germany, Denmark or Russia. Fig. 2 presents a schematic illustrating the organisational structure of the scientific school of Prof. Zavadskas.

\section{SCIENTIFIC ACHIEVEMENTS}

The authors believe that Edmundas Kazimieras Zavadskas has a personality which leaves an unforgettable impression. The next chapter is dedicated to two of the most outstanding traits of this prominent scientist, namely, creativity and the ability to accept and discuss new ideas. The earlier works by Prof. Zavadskas have been widely described in various papers (Kaplinski et al., 2014a; Kaplinski et al., 2014b; Kaplinski, 2009). This work presents a detailed description of scientific achievements by Professor and academician Zavadskas over the period of the last five years, when he focused on the investigation and solution of various sustainability problems (Fig. 3).

The number of research works in this field has been rapidly growing. It should be mentioned that solutions to sustainability problems are closely associated with MCDM strategies. This solidifies the importance of MCDM methods and their intense development. The increase in the number of papers on MCDM methods is shown in Fig. 4.

First, the new MCDM methods created with the participation of Prof. Zavadskas are described. The presented paper (Keshavarz Ghorabaee et al., 2018) offers a new original MCDM method that allows a simultaneous evaluation of criteria and alternatives (SECA) using a problem of multicriteria non-linear programming. The method aims for a more accurate evaluation of the significance of alternatives by con-

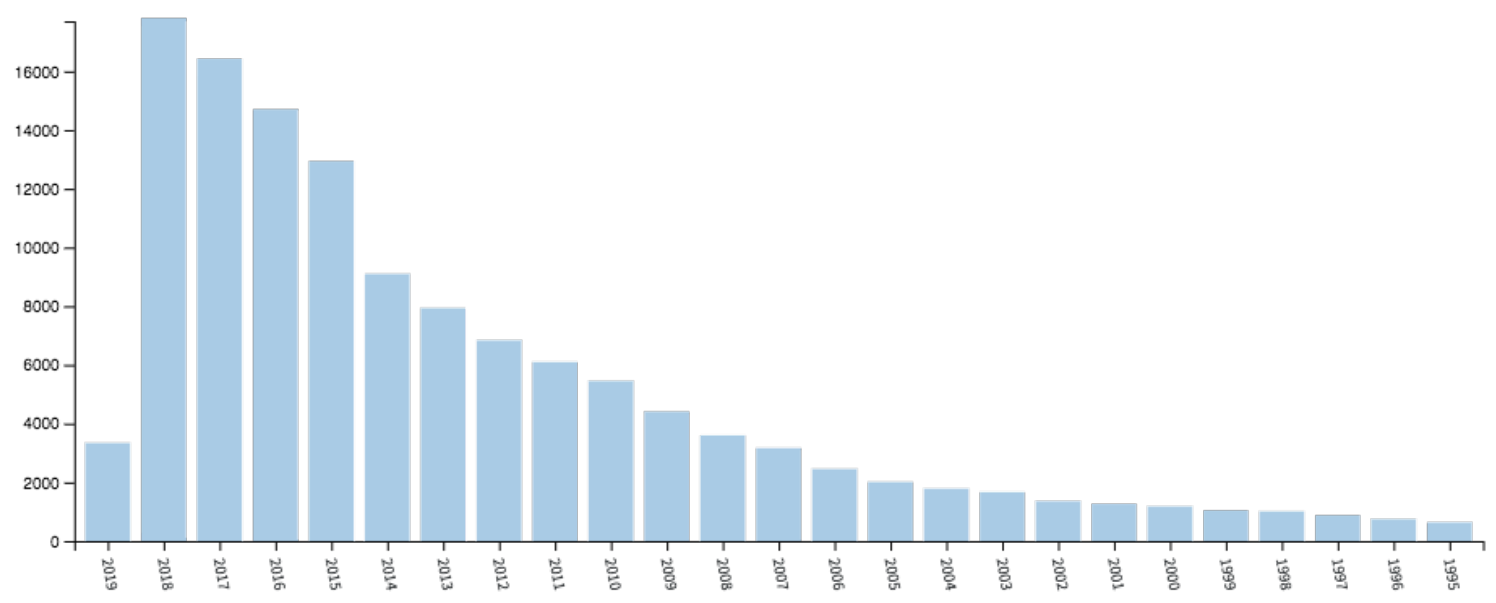

Fig.3. Increase in the number of papers dealing with sustainability problems

Source: author's elaboration on the basis of (Bausys, 2019, pp. 76-86). 


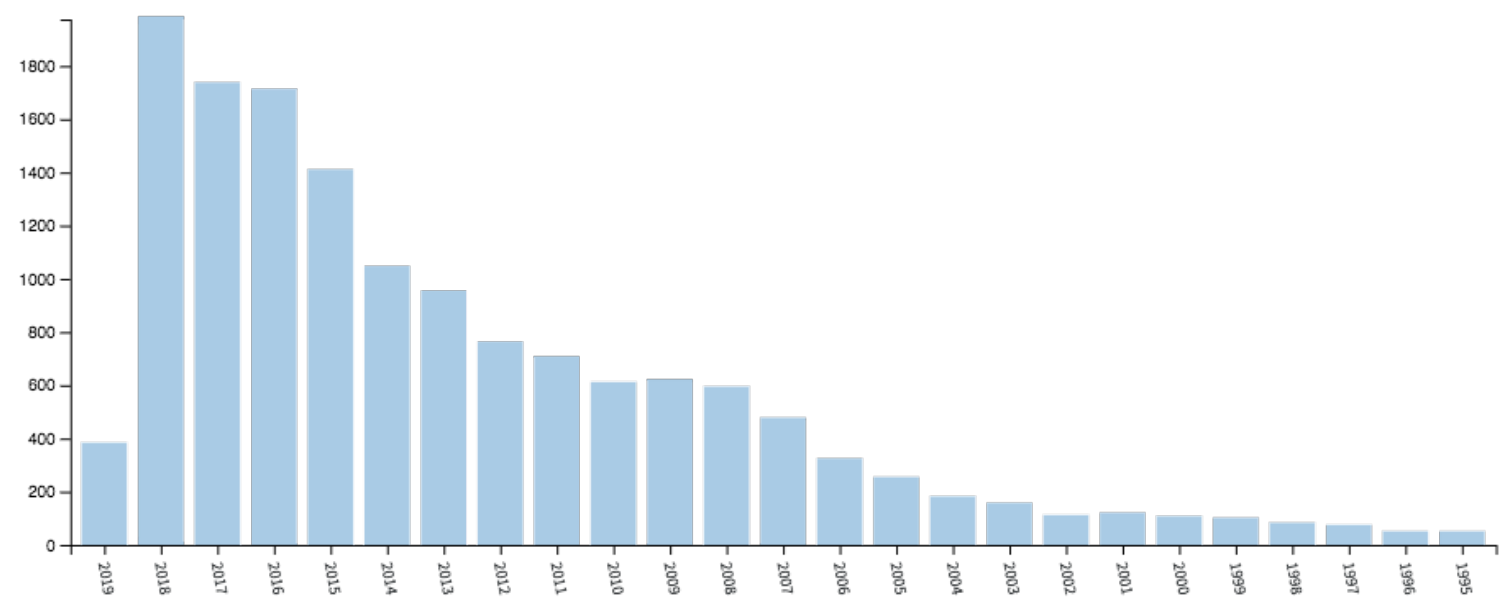

Fig. 4. Increase in the number of papers describing MCDM methods

Source: author's elaboration on the basis of (Bausys, 2019, pp. 76-86).

sidering the variation in solution matrix information, depending on particular criteria. As a result, the estimates of the alternatives and the weights of the criteria are calculated simultaneously.

In recent years, Prof. Zavadskas developed several methods for determining the weights of criteria. The accuracy in determining the criterion weights is very important for final results of MCDM problems. One of these approaches is WEBIRA based on the strategy of the weights balancing (Krylovas et al., 2017). This method is more effective in solving the considered problems described by a large number of criteria. Another method referred to as PIPRECIA (Stanujkic et al., 2017a) can be used for determining the weights of criteria when the consensus among experts cannot be achieved. This method allows determining the expert opinion about the significance of the particular criteria as well as the reliability of the obtained data. The modified KEMIRA method (Krylovas et al., 2016) aims to calculate the weights of criteria in the cases with several groups of criteria. In this case, experts assess the significance of the criteria in each group. Besides, this method requires much smaller amounts of the initial data compared to the original KEMIRA method and, therefore, the smaller amount of calculations. The original KEMIRA method was offered in (Krylovas et al., 2014). Its main idea was the use of the Kemeny's median for considering expert opinions. Three various metrics were used for calculating the median. Then, two other methods of the criterion weight determination were developed by Prof. Zavadskas et al. (Zavadskas \& Podvezko, 2016). The first method is CILOS, which is based on the analysis of variation in the criterion significance, considering changes in the significance values of other criteria. Another method, referred to as IDOCRIW, was developed based on using the best characteristics of the entropy method.

In recent years, Prof. Zavadskas focused on the development of new MCDM methods. The first two new methods were based on the properties of T-type fuzzy sets, and EAMRIT-2F was (Keshavarz Ghorabaee et al., 2016a) was the first among the two. It is used when MCDM problems are modelled in terms of the interval T-2 fuzzy sets. The optimality characteristic of this method is based on the area under the lower and upper membership function graphs as well as the probability analysis of the fuzzy sets. AFRAW is another original method (Keshavarz Ghorabaee et al., 2016c), which is also used when MCDM problems are modelled in terms of interval T-2 fuzzy sets. The method firstly calculates the weights of criteria by integrating the subjective data on the criterion weights provided by experts and the objective data on these weights, which are determined by using the deviation method. CODAS is yet another original MCDM method (Keshavarz Ghorabaee et al., 2016b), which helps to find the best alternative by using two metrics (Euclidian and Taxicab) simultaneously. The distances from the smallest (negative) ideal point are measured, which solves the problem of searching for the maximum. EDAS (Keshavarz Ghorabaee et al., 2015) is an MCDM method that allows selecting the best alternative based on the positive and negative deviations from the average solution. WS-PLP is an original decision-making method, based on summing up the weights and a new normalisation procedure, providing a decision-maker with a wider choice of the best and preferred alternatives (Stanujkic \& Zavadskas, 2015). The ARCAS method (Stanujkic 
et al., 2017b) is used for solving problems particular to group decision-making. According to this method, the best alternative is the one which is either awarded first places in the rating of alternatives or was indicated in the expert consensus. One of the most recently developed MCDM methods is the CoCoSo algorithm (Yazdani et al., 2018). This algorithm is based on the use of the combined compromise decision-making strategy, together with some data aggregation approaches.

In recent years, several authors published papers about the application of the methods developed by Prof. Zavadskas for the solution of various problems. The authors analysed the methods and the areas of their application: SWARA and WASPAS (Mardani et al., 2017a), various aspects of using the utility function (Mardani et al., 2018a), COPRAS (Stefano et al., 2015) and MULTIMOORA (Balezentis \& Balezentis 2014; Hafezalkotob et al., 2019).

In several papers, Prof. Zavadskas et al. focused on methodological principles of the MCDM method analysis (Zavadskas et al., 2014), the application of fuzzy sets (Mardani et al., 2015a), using the considered methods for solving the problems in various areas, such as determining the quality of services (Mardani et al., 2015c) and choosing suppliers (Keshavarz Ghorabaee et al., 2017a), as well as in power engineering (Mardani et al., 2015b; Mardani et al., 2017b; Siksnelyte et al., 2018), engineering (Zavadskas et al., 2016a), transport (Mardani et al., 2016b), sustainability (Zavadskas et al., 2016b), construction (Zavadskas et al., 2018a), supply chains (Soheilirad et al., 2018), etc. The principles were also used in the
VIKOR method (Mardani et al., 2016a), hybrid methods (Zavadskas et al., 2016b; Shen et al., 2018) and fuzzy aggregation operators (Mardani et al., 2018b).

Recently, Prof. Zavadskas offered several different method extensions adapted to deal with various sets e.g., the application of ARAS (Radovic et al., 2018) and SWARA (Zavadskas et al., 2018b) methods to the analysis of rough sets, the use of EDAS to deal with interval T2 fuzzy sets (Keshavarz Ghorabaee et al., 2017b), grey numbers (Stanujkic et al., 2017c), intuitionistic fuzzy sets (Kahraman et al., 2017; Keshavarz Ghorabaee et al., 2016b) and the stochastic problem solution (Keshavarz Ghorabaee et al., 2017c), as well as the use of the entropy method in the KEMIRA method (Krylovas et al., 2017). Now, MCDM problems are solved using new neutrosophic sets. The application can range from the market value determination (Zavadskas et al., 2017c), the use of the extensions of MULTIMOORA (Stanujkic et al., 2017e; Zavadskas et al., 2017b), the WASPAS method (Zavadskas et al., 2015), the application of VIKOR to deal with the interval neutrosophic sets (Bausys \& Zavadskas, 2015) and COPRAS with ordinary neutrosophic sets (Bausys et al., 2015). Other notable achievements of Prof. Zavadskas include the extension of the WASPAS method for dealing with fuzzy sets (Keshavarz Ghorabaee et al., 2016a; Turskis et al., 2015), the MULTIMOORA method for interval triangular fuzzy numbers (Stanujkic et al., 2015), the extension of the COPRAS method (Roy et al., 2019), COPRAS-WIRN (Zolfani et al., 2018), the extension of SWARA (Hashemi et al., 2016), the CODAS

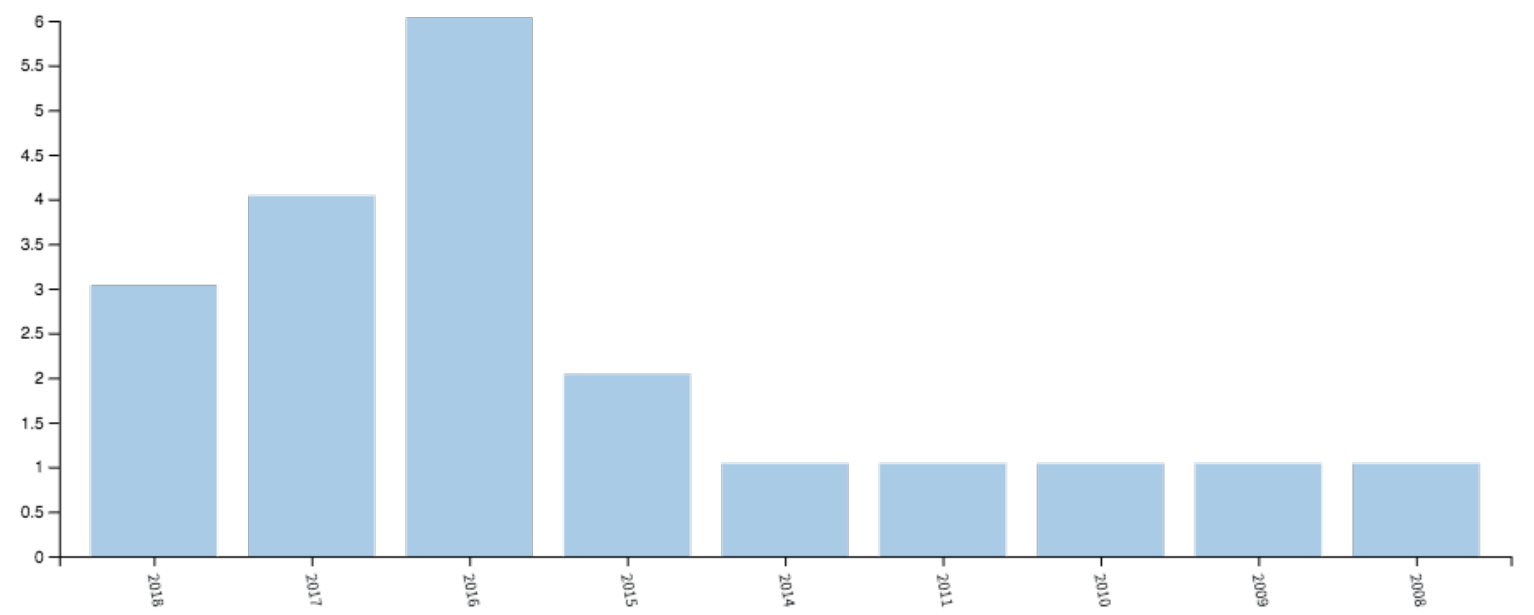

Fig. 5. Annual changes in the number of the most often cited papers by Prof. Zavadskas

Source: author's elaboration on the basis of (Bausys, 2019, pp. 76-86). 
method (Seker \& Zavadskas, 2017), the extensions of the OCRA method applied to grey numbers (Stanujkic et al., 2017d) and the extensions of the ELECTRE method (Jahan \& Zavadskas, 2019; Hashemi et al., 2016).

Recently, the research achievements of Prof. Zavadskas received international recognition. Twenty of his works were included in the list of the most frequently cited papers (Fig. 5), which illustrates an exceptionally high quality of research works produced by Prof. Zavadskas et al.

\section{CONCLUSIONS}

The trans-border Lithuanian-German-Polish co-operation in the area of MCDM, operational and sustainable development is currently counting its 33 rd year. It is a good example of international collaboration, which has resulted in numerous highquality publications and was recognised by scientific communities. This cooperation created a platform for the exchange of experience and inspired to establish new directions for scientific research. It especially aided in the creation of new instruments for planning and decision-making. Professor Zavadskas is both an originator and a co-creator of this concept; therefore, he is rightfully praised for his numerous documented scientific achievements and the promotion of the scientific development of the Colloquia participants.

Notwithstanding the three-sided cooperation between Lithuania, Germany and Poland, the scientific school of Professor Zavadskas at Vilnius Gediminas Technical University is an exemplary educational facility. Its domain is the promotion of young scientists, i.e. doctoral students. It is already the third generation of the Professor's academic students who have become doctors. The MDCM topic has always stood out in the area of team work, and the achieved results have been applied in various fields of technical, economic and social sciences. The reach of the school is international. Now, scientific works address new research areas dealing with biometrics and neurosophia.

On the occasion of the 75th birthday, we would like to wish Professor Edmundas K. Zavadskas good health, many more personal successes and joy observing the growth achieved by his students, as well as offer him sincere gratitude for many years of laborious yet fruitful efforts.

\section{LITERATURE}

Balezentis, T., \& Balezentis, A. (2014). A Survey on Development and Applications of the Multi-criteria Decision Making Method MULTIMOORA. Journal of Multi-Criteria Decision Analysis, 21(3-4), 209-222.

Bausys, R. (2019). Mokslinių pasiekimų puokštè. In: A. Binkyte-Vèliene (Ed.), O. Jursaite (Ed.), Neprarasty dienu metai. Akademikas Edmundas Kazimieras Zavadskas. II dalis. (pp. 76-86). Vilnius: Technika. doi: 10.20334/2019-011-P.

Bausys, R., \& Zavadskas, E. K. (2015). Multicriteria decision making approach by VIKOR under interval neutrosophic set environment. Economic Computation and Economic Cybernetics Studies and Research, 49(4), 33-48.

Bausys, R., Zavadskas, E. K., \& Kaklauskas, A. (2015). Application of neutrosophic set to multicriteria decision making by COPRAS. Economic Computation and Economic Cybernetics Studies and Research, 49(2), 91-106.

Ginevicius, R., Podvezko, V., \& Bruzge, S. (2008). Evaluating the effect of state aid to business by multicriteria methods. Journal of Business Economics and Management, 9(3), 167-180.

Hafezalkotob, A., Hafezalkotob, A., Liao, H., \& Herrera, F. (2019). An overview of MULTIMOORA for multicriteria decision-making: Theory, developments, applications, and challenges. Information Fusion, 51, 145-177.

Hashemi, S. S., Razavi, H, Hajiagha, S. H. R., Zavadskas, E. K., \& Mahdiraji, H. A. (2016). Multicriteria group decision making with ELECTRE III method based on interval-valued intuitionistic fuzzy information. Applied Mathematical Modelling, 40(2), 1554-1564. doi: 10.1016/j.apm.2015.08.011.

Jahan, A., \& Zavadskas, E. K. (2019). ELECTRE-IDAT for design decision-making problems with interval data and target-based criteria. Soft Computing, 23(1), 129143. doi:10.1007/s00500-018-3501-6.

Kahraman, C., Keshavarz Ghorabaee, M., Zavadskas, E. K., Cevik Onar, S., Yazdani, M., \& Oztaysi, B. (2017). Intuitionistic fuzzy EDAS method: an application to solid waste disposal site selection. Journal of Environmental Engineering and Landscape Management, 25(1), 1-12. doi: 10.3846/16486897.2017.1281139.

Kaplinski, O., Peldschus, F., \& Tamosaitiene, J. (2014a). Professor Edmundas Kazimieras Zavadskas: his academic research, school of thought, and most eminent results of his work. Archives of Civil Engineering, 60(2), 287-292.

Kaplinski, O., Peldschus, F., \& Tupenaite, L. (2014b). Development of MCDM Methods - in honour of professor Edmundas Kazimieras Zavadskas on the occasion of his 70th birthday. International. Journal of Computers, Communications \& Control, 9(3), 305-312.

Kaplinski, O. (2009). Sapere Aude: Professor Edmundas Kazimieras Zavadskas. Inzinerine ekonomika-Engineering Economics, 65(5), 113-119.

Keshavarz Ghorabaee, M., Amiri, M., Zavadskas, E. K., Turskis, Z., \& Antucheviciene, J. (2018). Si- 
multaneous evaluation of criteria and alternatives (SECA) for multi-criteria decisionmaking. Informatica, 29(2), 265-280. doi: 10.15388/Informatica.2018.167.

Keshavarz Ghorabaee, M., Amiri, M., Zavadskas, E. K., Turskis, Z., \& Antucheviciene, J. (2017b). A new multi-criteria model based on interval type-2 fuzzy sets and EDAS method for supplier evaluation and order allocation with environmental considerations. Computers \& Industrial Engineering, 112, 156174. doi:10.1016/j.cie.

Keshavarz Ghorabaee, M., Amiri, M., Zavadskas, E. K., Turskis, Z., \& Antucheviciene, J. (2017c) Stochastic EDAS method for multi-criteria decisionmaking with normally distributed data. Journal of Intelligent \& Fuzzy Systems, 33(3), 1627-1638. doi: 10.3233/JIFS-17184.

Keshavarz Ghorabaee, M., Maghsoud, A., Zavadskas, E. K., \& Antucheviciene, J. (2017a). Supplier evaluation and selection in fuzzy environments: a review of MADM approaches. Economic ResearchEkonomska Istraživanja, 30(1), 1073-1118. doi: 10.1080/1331677X.2017.1314828.

Keshavarz Ghorabaee, M., Zavadskas, E. K., Amiri, M., \& Antucheviciene, J. (2016a). Evaluation by an Area-based Method of Ranking Interval Type-2 Fuzzy sets (EAMRIT-2f) for multi-criteria group decisionmaking. Transformations in Business \& Economics, 15, 3(39), 76-95.

Keshavarz Ghorabaee, M., Zavadskas, E. K., Amiri, M., \& Antucheviciene, J. (2016b). A new method of Assessment based on Fuzzy Ranking and Aggregated Weights (AFRAW) for MCDM problems under type-2 fuzzy environment. Economic Computation and Economic Cybernetics Studies and Research, 50(1), 39-68.

Keshavarz Ghorabaee, M., Zavadskas, E. K., Amiri, M., \& Esmaeili, A. (2016a). Multi-criteria evaluation of green suppliers using an extended WASPAS method with interval type-2 fuzzy sets. Journal of Cleaner Production, 137, 213-229. doi:10.1016/ j.jclepro.2016.07.031.

Keshavarz Ghorabaee, M., Zavadskas, E. K., Amiri, M., \& Turskis, Z. (2016b). Extended EDAS method for fuzzy multi-criteria decision-making: an application to supplier selection. International Journal of Computers, Communications \& Control, 11(3), 358-371.

Keshavarz Ghorabaee, M., Zavadskas, E. K., Olfat, L., \& Turskis, Z. (2015). Multi-criteria inventory classification using a new method of Evaluation based on Distance from Average Solution (EDAS). Informatica, 26(3), 435-451.

Keshavarz Ghorabaee, M., Zavadskas, E. K., Turskis, Z., \& Antucheviciene, J. (2016c). A new combinative distance-based assessment (CODAS) method for multi-criteria decision-making. Economic Computation and Economic Cybernetics Studies and Research, 50(3), 25-44.

Krylovas, A., Dadelo, S., Kosareva, N., \& Zavadskas, E. K. (2017). Entropy-KEMIRA approach for MCDM problem solution in human resources selection task. International Journal of Information Technology \& Decision Making, 16(5), 1183-1209.
doi:10.1142/S0219622017500274.

Krylovas, A., Kosareva, N., \& Zavadskas, E. K. (2017). WEBIRA - comparative analysis of weight balancing method. International Journal of Computers, Communications \& Control, 12(2), 238-253. doi: 10.15837/ijccc.2017.2.2844.

Krylovas, A., Zavadskas, E. K., \& Kosareva, N. (2016). Multiple criteria decision-making KEMIRA-M method for solution of location alternatives. Economic Research-Ekonomska Istraživanja, 29(1), 50-65. doi: 10.1080/1331677X.2016.1152560.

Krylovas, A., Zavadskas, E. K., Kosareva, N., \& Dadelo, S. (2014). New KEMIRA method for determining criteria priority and weights in solving MCDM problem. International Journal of Information Technology \& Decision Making, 13(6), 1119-1134. doi: 10.1142/ S0219622014500825.

Mardani, A., Jusoh, A., \& Zavadskas, E. K. (2015a). Fuzzy multiple criteria decision-making techniques and applications - Two decades review from 1994 to 2014. Expert Systems with Applications, 42(8), 4126-4148. doi: 10.1016/j.eswa.2015.01.003.

Mardani, A., Jusoh, A., Halicka, K., Ejdys, J., Magruk, A., Norulkamar, U., \& Ahmad, U. (2018a). Determining the utility in management by using multicriteria decision support tools: a review. Economic Research-Ekonomska Istraživanja, 31(1), 1666-1716. doi: 10.1080/1331677X.2018.1488600.

Mardani, A., Jusoh, A., Zavadskas, E. K., Cavallaro, F., \& Khalifah, Z. (2015b). Sustainable and renewable energy: an overview of the application of multiple criteria decision making techniques and approaches: review. Sustainability, 7(10), 13947-13984. doi:10.3390/su71013947.

Mardani, A., Jusoh, A., Zavadskas, E. K., Khalifah, Z., \& Nor MD, K. (2015c). Application of multiplecriteria decision-making techniques and approaches to evaluating of service quality: a systematic review of the literature. Journal of Business Economics and Management, 16(5), 1034-1068. doi: 10.3846/16111699.2015.1095233.

Mardani, A., Nilashi, M., Zakuan, N., Loganathan, N., Soheilirad, S., Saman, M. Z. M., \& Ibrahim, O. (2017a). A systematic review and meta-analysis of SWARA and WASPAS methods: theory and applications with recent fuzzy developments. Applied Soft Computing, 57, 265-292. doi: 10.1016/j.asoc.2017.03.045.

Mardani, A., Nilashi, M., Zavadskas, E. K., Awang, S. R., Zare, H., \& Jamal, N. M. (2018b). Decision Making Methods Based on Fuzzy Aggregation Operators: Three Decades Review from 1986 to 2017. International Journal of Information Technology \& Decision Making, 17(2), 391-466. doi: 10.1142/ S021962201830001X.

Mardani, A., Zavadskas, E. K., Govindan, K., Senin, A. A., \& Jusoh, A. (2016a). VIKOR Technique: A Systematic Review of the State of the Art Literature on Methodologies and Applications. Sustainability, 8(1), 37. doi: $10.3390 /$ su8010037.

Mardani, A., Zavadskas, E. K., Khalifah, Z., Jusoh, A., \& Nor MD, K. (2016b). Multiple criteria decisionmaking techniques in transportation systems: a systematic review of the state of the art literature. Trans- 
port, 31(3), 359-385. doi:10.3846/16484142.2015.112 1517.

Mardani, A., Zavadskas, E. K., Khalifah, Z., Zakuan, N., Jusoh, A., Md Nor, K., \& Khoshnoudi, M. (2017b). A review of multi-criteria decision-making applications to solve energy management problems: Two decades from 1995 to 2015. Renewable \& Sustainable Energy Reviews, 71, 216-256. doi: 10.1016/ j.rser.2016.12.053.

Radovic, D., Stevic, Z., Pamucar, D., Zavadskas, E. K., Badi, I., Antucheviciene, J., \& Turskis, Z. (2018). Measuring performance in transportation companies in developing countries: a novel rough ARAS model. Symmetry, 10(10), 1-24. doi: 10.3390/sym10100434.

Roy, J., Sharma, H. K., Kar, S., Zavadskas, E. K., \& Saparauskas, J. (2019). An extended COPRAS model for multi-criteria decision-making problems and its application in web-based hotel evaluation and selection. Economic Research-Ekonomska Istraživanja, 32(1), 219-253. doi: 10.1080/1331677X.2018.1543054.

Seker, S., \& Zavadskas, E. K. (2017). Application of fuzzy DEMATEL method for analyzing occupational risks on construction sites. Sustainability, 9(11), 1-19. doi: $10.3390 /$ su9112083.

Shen, K.-Y., Zavadskas, E. K., \& Tzeng, G.-H. (2018). Updated discussions on 'Hybrid multiple criteria decision-making methods: a review of applications for sustainability issues'. Economic ResearchEkonomska Istraživanja, 31(1), 1437-1452. doi: 10.1080/1331677X.2018.1483836.

Siksnelyte, I., Zavadskas, E. K., Streimikiene, D., \& Sharma, D. (2018). An overview of multicriteria decisionmaking methods in dealing with sustainable energy development issues. Energies, 11(10). doi: 10.3390/ en 11102754

Soheilirad, S., Govindan, K., Mardani, A., Zavadskas, E. K., Nilashi, M., \& Zakuan, N., (2018). Application of data envelopment analysis models in supply chain management: a systematic review and meta-analysis. Annals of Operations Research, 271(2), 915-969.

Stanujkic D., \& Zavadskas, E. K. (2015). A Modified Weighted Sum Method Based on the Decision-maker's Preferred Levels of Performances. Studies in Informatics and Control, 24 (4), 461-470. doi:10.24846/ v24i4y201510.

Stanujkic, D., Zavadskas, E. K, Keshavarz Ghorabaee, M., \& Turskis, Z. (2017c). An extension of the EDAS method based on the use of interval grey numbers. Studies in Informatics and Control, 26(1), 5-12.

Stanujkic, D., Zavadskas, E. K., Brauers, W. K. M., \& Karabasevic, D. (2015). An extension of the multimoora method for solving complex decision-making problems based on the use of interval-valued triangular fuzzy numbers. Transformations in Business \& Economics, 14(2B (35B)), 355-375.

Stanujkic, D., Zavadskas, E. K., Karabasevic, D., Smarandache, F., \& Turskis, Z. (2017a). The use of the pivot pairwise relative criteria importance assessment method for determining the weights of criteria. Romanian Journal of Economic Forecasting, 20(4), 116133.

Stanujkic, D., Zavadskas, E. K., Karabasevic, D., Turskis, Z., \& Kersuliene, V. (2017b). New group decision-making ARCAS approach based on the integration of the SWARA and the ARAS methods adapted for negotiations. Journal of Business Economics and Management, 18(4), 599-618. doi: 10.3846/16111699.2017.1327455.

Stanujkic, D., Zavadskas, E. K., Liu, S., Karabasevic, D., \& Popovic, G. (2017d). Improved OCRA method based on the use of interval grey numbers. Journal of Grey System, 29(4), 49-60.

Stanujkic, D., Zavadskas, E. K., Smarandache, F., Brauers, W. K. M., \& Karabasevic, D. (2017e). A neutrosophic extension of the MULTIMOORA method. Informatica, 28(1), 181-192. doi:10.15388/Informatica.2017.125.

Stefano, N. M., Casarotto Filho, N., Vergara, L. G. L., \& Rocha, R. U. G. (2015). COPRAS (Complex Proportional Assessment): state of the art research and its applications. IEEE Latin America Transactions, 13(12), 3899- 3906.

Tamosaitiene, J. (2019). Lietuvos mokslų akademijos akademiko prof. habil. Dr. Edmundo Kazimiero Zavadsko mokslinè mokykla. In: A. Binkyte-Vèliene (Ed.), O. Jursaite (Ed.), Neprarastu dienu metai. Akademikas Edmundas Kazimieras Zavadskas. II dalis. (pp. 64-75). Vilnius: Technika. doi: 10.20334/2019-011-P.

Tamosaitiene, J., Bartkiene, J., \& Vilutiene, T. (2010). The new development trend of operational research in civil engineering and sustainable development as a result of collaboration between German-Lithuanian-Polish scientific triangle. Journal of Business Economics and Management, 11(2), 316-340.

Turskis, Z. (2008). Multi-attribute contractors ranking method by applying Ordering of feasible alternatives of solutions in terms of preferability technique. Technological and Economic Development of Economy, $14(2), 224-239$.

Turskis, Z., Zavadskas, E. K., Antucheviciene, J., \& Kosareva, N. (2015). A hybrid model based on Fuzzy AHP and Fuzzy WASPAS for construction site selection. International Journal of Computers, Communications \& Control, special issue on fuzzy sets and applications (celebration of the $50^{\text {th }}$ anniversary of fuzzy sets), 10(6), 873-888.

Vilutiene, T. (2019). EURO darbo grupe “The OR in Sustainable Development and Civil Engineering” (EWG ORSDCE) iniciatyva tvarumui didinti statybos sektoriuje. In: A. Binkyte-Vèliene (Ed.), O. Jursaite (Ed.), Neprarastu dienu metai. Akademikas Edmundas $\mathrm{Ka}$ zimieras Zavadskas. II dalis. (pp. 87-92). Vilnius: Technika. doi: 10.20334/2019-011-P.

Yazdani, M., Zarate, P., Zavadskas, E. K., \& Turskis, Z. 2018. A combined compromise solution (CoCoSo) method for multi-criteria decision-making problems. Management Decision, In press: doi: 10.1108/ MD-05-2017-0458.

Zavadskas E. K., Bausys R., Juodagalviene B., \& GarnyteSapranaviciene I. (2017b). Model for residential house element and material selection by neutrosophic MULTIMOORA method. Engineering Applications of Artificial Intelligence, 64, 315-324.

Zavadskas, E. K., \& Podvezko, V. (2016). Integrated determination of objective criteria weights in MCDM. International Journal of Information Technology 
\& Decision Making, 15(2), 267-283. doi: 10.1142/ S0219622016500036.

Zavadskas, E. K., Antucheviciene, J., Turskis, Z., \& Adeli, H. (2016a). Hybrid multiple-criteria decision-making methods: a review of applications in engineering. Scientia Iranica, 23(1), 1-20.

Zavadskas, E. K., Antucheviciene, J., Vilutiene, T., \& Adeli, H. (2018a). Sustainable decision-making in civil engineering, construction and building technology. Sustainability, 10(1), 1-21. doi: 10.3390/su10010014.

Zavadskas, E. K., Bausys R., \& Lazauskas M. (2015). Sustainable assessment of alternative sites for the construction of a waste incineration plant by applying WASPAS method with single-valued neutrosophic set. Sustainability, 7(12), 15923-15936.

Zavadskas, E. K., Bausys, R., Kaklauskas, A., Ubarte, I., Kuzminske, A., \& Gudiene, N. (2017c). Sustainable market valuation of buildings by the single-valued neutrosophic MAMVA method. Applied Soft Computing, 57, 74-87. doi: 10.1016/j.asoc.2017.03.040.

Zavadskas, E. K., Govindan, K., Antucheviciene, J., \& Turskis, Z. (2016b). Hybrid multiple criteria decision-making methods: a review of applications for sustainability issues. Economic ResearchEkonomska Istraživanja, 29(1), 857-887. doi: 10.1080/1331677X.2016.1237302.

Zavadskas, E. K., Kaklauskas, A., Turskis, Z., \& Tamosaitiene, J. (2008). Selection of the effective dwelling house walls by applying attributes values determined at intervals. Journal of Civil Engineering and Management, 14(2), 85-93.

Zavadskas, E. K., Stevic, Z., Tanackov, I., \& Prentkovskis, O. (2018b). A novel multicriteria approach - Rough Step-wise Weight Assessment Ratio Analysis method (R-SWARA) and its application in logistics. Studies in informatics and control. Bucharest: National Institute for Research \& Development in Informatics, 27(1), 97-106. doi: 10.24846/v27i1y201810.

Zavadskas, E. K., Turskis, Z., \& Kildiene, S. (2014). State of art surveys of overviews on MCDM/ MADM methods. Technological and Economic Development of Economy, 20(1), 165-179. doi: 10.3846/20294913.2014.892037.

Zolfani, S. H., Yazdani, M., \& Zavadskas, E. K. (2018). An extended stepwise weight assessment ratio analysis (SWARA) method for improving criteria prioritization process. Soft Computing, 22(22), 7399-7405. doi: 10.1007/s00500-018-3092-2. 